\title{
Pemetaan Efek Spasial pada Data Kemiskinan Kota Bengkulu
}

\author{
Spatial Effect Mapping for Poverty Data in Bengkulu City \\ Harmes $^{1 *}$, Bambang Juanda ${ }^{2}$, Ernan Rustiadi ${ }^{3} \&$ Baba Barus $^{3}$ \\ ${ }^{1}$ Program Studi Ilmu Perencanaan Pembangunan Wilayah dan Perdesaan, Institut Pertanian Bogor, Kampus \\ IPB Dramaga, Bogor 16680; ${ }^{2}$ Fakultas Ekonomi dan Manajemen, Departemen Ekonomi, Institut Pertanian \\ Bogor, Kampus IPB Dramaga, Bogor $16680 ;{ }^{3}$ Fakultas Pertanian, Institut Pertanian Bogor, Kampus IPB \\ Dramaga, Bogor 16680; ${ }^{*}$--mail:harmesharmes@gmail.com
}

(Diterima: 22 Mei 2017; Disetujui: 25 Juli 2017)

\begin{abstract}
Anti-poverty programs and policies are designed similar for all regions in Indonesia, disregarding the local socio-culture and the poverty spatial pattern of the regions. The approach is based on central government's program and not based on each region's locality. This generic programming approach caused the achievement of development goals decline. The effect of space on poverty can be identified by the presence of spatial autocorrelation, which is the link between the examined variable to itself in a spatial manner or commonly referred to as spatial dependence. The aim of this paper is to investigate the global and local spatial autocorrelation for micro poverty data set in Bengkulu City in order to identify spatial approach for its anti-poverty program. Global Moran Index (MI) tests identifies the overall occurrence of autocorrelation, meanwhile the local spatial test shows which subdistricts has the presence of autocorrelation. Global and local MI are popular tools utilized to calculate the spatial effect, particularly to present spatial dependencies. The relation between urban village linkages obtained an MI value of 0.322. This MI value indicates the presence of spatial autocorrelation for subdistricts located in cluster. In local spatial effect observation using Local Indicator of Spatial Autocorrelation (LISA), its discovered that there are several subdistricts having autocorrelation, meanwhile the rest are not significant. Cluster mapping on global MI and LISA shows high-high poverty districts are located in the south of the city, low-high poverty districts in the east, and low-low high-low poverty districts near the city center.
\end{abstract}

Keyword: mapping cluster, Moran Index, poverty, spatial autocorrelation.

\begin{abstract}
ABSTRAK
Program dan kebijakan anti kemiskinan dirancang seragam untuk seluruh wilayah di Indonesia, mengabaikan kekhasan sosio-kultural dan pola geografis masing-masing wilayah yang mempengaruhi keberadaan penduduk miskin. Pendekatan ini lebih berorientasi pada program pemerintah dan tidak berbasis situasi riil yang menjadi lokalitas wilayah. Generalisasi pemrograman seperti ini menyebabkan pencapaian tujuan pembangunan mengalami penurunan, yang terlihat dari semakin lambannya laju penurunan persentase penduduk miskin di Indonesia pada dekade terakhir. Efek ruang terhadap kemiskinan dapat diidentifikasi dengan adanya autokorelasi spasial, yakni keterkaitan antara variabel yang diteliti dan dirinya sendiri secara spasial atau biasa juga disebut sebagai ketergantungan spasial. Tulisan ini ditujukan untuk menginvestigasi adanya autokorelasi spasial global dan lokal pada data kemiskinan Kota Bengkulu, dalam upaya penanggulangan kemiskinan. Indeks Moran global dan lokal biasa digunakan untuk menghitung adanya efek spasial, khususnya ketergantungan spasial.
\end{abstract}


Uji spasial global hanya mengidentifikasi adanya autokorelasi spasial, sedangkan uji spasial lokal menunjukkan wilayah mana saja yang memiliki autokorelasi. Hubungan antar wilayah yang ditunjukkan dengan nilai sebesar 0.322 mengindikasikan adanya autokorelasi yang menggerombol untuk data kemiskinan se-kota Bengkulu. Nilai ini mengandung makna bahwa kelurahan yang berdekatan memiliki karakteristik kemiskinan yang relatif sama. Uji efek spasial lokal dengan indeks LISA menunjukkan hanya beberapa kelurahan saja yang memiliki autokorelasi, kebanyakan lainnya tidak signifikan. Hasil pemetaan cluster memperlihatkan kelurahan yang kemiskinannya tinggi dan dikelilingi oleh wilayah dengan kondisi yang sama (tinggi-tinggi) terjadi di arah selatan kota, wilayah yang rendah-rendah di pusat kota, sedangkan wilayah dengan kemiskinan rendahtinggi berlokasi di bagian timur dan yang tinggi-rendah berada di pusat kota.

Kata kunci: autokorelasi spasial, Indeks Moran, kemiskinan, pemetaan cluster.

\section{PENDAHULUAN}

Isu strategis pembangunan di Indonesia masih didominasi oleh kemiskinan. Badan Pusat Statistik (BPS) melaporkan persentase penduduk nasional di bawah garis kemiskinan telah dapat diturunkan dari $15.1 \%$ di tahun 1990 menjadi $10.96 \%$ di 2014. Namun periode Maret 2015, jumlah penduduk miskin mencapai 28.59 juta orang $(11.22 \%)$ atau bertambah sebesar 0.86 juta orang dibandingkan dengan kondisi September 2014, secara agregat di perdesaan dan perkotaan terjadi kenaikan sebesar $1.26 \%$.

Pendekatan pembangunan dan upaya penanggulangan kemiskinan selama ini diformulasikan secara generik untuk seluruh wilayah. Penetapan Rumah Tangga Sasaran (RTS) upaya penanggulangan kemiskinan belum mempertimbangkan efek spasial kemiskinan. Efek ini berupa ketergantungan spasial (spatial dependency) dan keragaman spasial (spatial heterogeinity).

Kebijakan penanggulangan kemiskinan yang dilandasi Instruksi Presiden No. 15/2010 tentang Upaya Percepatan Penanggulangan Kemiskinan, didominasi oleh inisiatif dari pemerintah pusat yang bersifat top down dan teknokratik. Kebijakan dengan injeksi dari luar seperti ini menyebabkan kurang berkembangnya inisiatif, partisipasi dan sensitivitas masyarakat serta pemerintah lokal. Formulasi program anti kemiskinan yang seragam juga membuktikan kurangnya keterlibatan pemerintah dan masyarakat lokal dalam pemrograman upaya penanggulangan kemiskinan.

BPS pada tahun 2011 merilis jumlah penduduk miskin Kota Bengkulu mencapai $17.36 \%$, dengan tingkat kedalaman kemiskinan $2.97 \%$ yang melebihi rata-rata nasional yakni $1.52 \%$, sedangkan tingkat keparahan kemiskinan $0.74 \%$ dan nasional adalah $0.39 \%$. Kondisi ini mencerminkan tingginya kemiskinan di Kota Bengkulu dibandingkan dengan kondisi nasional.

Saat ini pendataan penduduk miskin yang menjadi sasaran kebijakan, diperoleh dari sensus terhadap $40 \%$ penduduk Indonesia dengan tingkat kesejahteraan terendah yang diidentifikasi by name by address oleh Tim khusus Badan Pusat Statistik tahun 2011. Tim Nasional Percepatan Penanggulangan Kemiskinan (TNP2K) mengambil $40 \%$ data tersebut sesuai urutan dari yang terendah di setiap daerah sebagai rumah tangga sasaran dalam Kebijakan Penanggulangan Kemiskinan. Jumlah penduduk miskin yang dirilis BPS hampir sama dengan $10 \%$ penduduk Indonesia dengan tingkat kesejahteraan paling rendah pada Basis Data Terpadu (BDT) TNP2K. Salah satu perbaikan data program penanggulangan kemiskinan untuk perlindungan sosial pemerintah, swasta dan masyarakat, telah dibangun BDT dengan PSE 2005 yang mencapai 19.1 juta rumah tangga, PPLS 2008 sebanyak 18.5 juta rumah tangga, PPLS 2011 sebanyak 25 juta rumah tangga. 


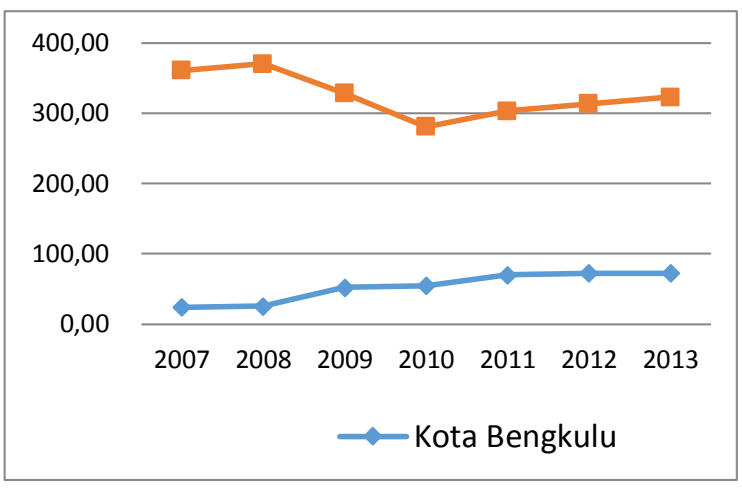

Gambar 1. Tren perkembangan penduduk miskin Kota Bengkulu dan Provinsi Bengkulu dan (BPS, 2015).

Tren kemiskinan pada Gambar 1 mengindikasikan adanya peningkatan angka kemiskinan di Kota dan Provinsi Bengkulu, meskipun modifikasi dengan perbaikan pada program anti kemiskinan sudah dilakukan oleh pemerintah, namun kenyataannya masih meninggalkan banyak permasalahan baik dalam skala nasional maupun lokal, secara statistik nampak dari semakin melambatnya laju penurunan jumlah penduduk miskin.

Rustiadi et al. (2009), Hakim dan Zuber (2008), Thaib (2008) dan Syafitri et al. (2008), mengemukakan bahwa kajian pemrograman pembangunan khususnya upaya penanggulangan kemiskinan harus memperhatikan unsur spasial atau lokasi sehingga kegagalan program dapat diminimalisasi. Lipton (2009) menunjukkan reformasi agraria merupakan salah satu instrumen mereduksi kemiskinan di negara berkembang, khususnya wilayah perdesaan. Konsep agraria sebagai sumber daya lahan adalah kontektualisasi ruang yang di atasnya berlangsung aktivitas manusia, termasuk kejadian kemiskinan.

Kemiskinan didefinisikan sebagai suatu keadaan dimana tingkat pendapatan seseorang menyebabkan dirinya tidak dapat mengikuti tata nilai dan norma-norma yang berlaku di masyarakat (Rustiadi et al., 2009). Chambers (1977) dalam Nasution (2015) menyebutkan ada lima dimensi ketidakberuntungan yang berinteraksi satu sama lain dan memerangkap orang miskin, yaitu: 1) kemiskinan itu sendiri (poverty), 2) kelemahan fisik (physical weakness) 3) keterasingan (isolation) baik secara geografis maupun sosiologis, 4) kerentanan menghadapi situasi darurat (state of emergency), 5) ketidakberdayaan (powerless).

Kenyataan di atas membutuhkan upaya perluasan pendekatan spasial dalam penyusunan program anti kemiskinan yang dijalankan pemerintah maupun lembaga non pemerintah. Kemiskinan sebagai isu pembangunan lokal secara lokalitas memiliki keterkaitan erat dengan faktor lokasional dimana fenomena ini terjadi.

\section{METODOLOGI}

Permasalahan kemiskinan pada dasarnya bukan hanya persoalan ekonomi semata, tetapi bersifat kompleks dan multidimensi. Konsep dasar kemiskinan yang dikemukan Laderchie $e t$ al. (2003) meliputi pendekatan moneter, kapabilitas individu, pengucilan sosial dan partisipasi orang miskin menunjuk adanya kenyataan kemiskinan yang terkait erat persoalan-persoalan seperti sosial, budaya, politik termasuk juga persoalan fisik wilayah atau spasial. Adanya keterkaitan spasial pada kemiskinan membutuhkan pendekatan baru yang mengintegrasikan pengaruh spasial dalam fokus kajian kemiskinan, sehingga solusi pengentasan kemiskinan tidak homogen, namun memperhatikan heterogenitas spasial yang ada.

\section{Data}

Seluruh data spasial dasar penelitian disiapkan dengan tingkat kedetilan minimal skala 1:10.000. Sumber data berasal dari Pemerintah Kota Bengkulu, Badan Informasi Geospasial (BIG) dan survei lapangan. Variabel kemiskinan adalah jumlah agregat penduduk miskin sesuai publikasi BPS, dan diproksi dari BDT-TNP2K untuk wilayah Kota Bengkulu. 


\section{Lokasi Penelitian}

Wilayah penelitian meliputi 9 kecamatan dan 67 kelurahan se-kota Bengkulu. Kecamatan Muara Bangkahulu terdiri atas 7 kelurahan, Kecamatan Sungai Serut 7 kelurahan, Kecamatan Teluk Segara 13 kelurahan, Kecamatan Ratu Samban 9 kelurahan, Kecamatan Ratu Agung 8 kelurahan, Kecamatan Gading Cempaka 11 kelurahan, Kecamatan Selebar 6 kelurahan dan kecamatan Kampung Melayu sebanyak 6 kelurahan.

\section{Teknik Analisis}

\section{Analisis Spasial Moran 's I}

Pola spasial kemiskinan yang menunjukkan distribusi sesuatu kejadian di atas ruang dianalisis dengan indeks Moran's serta divisualisasikan melalui Moran 's scatter plot dan peta cluster data kemiskinan. Pola spasial sesuai indeks Moran 's mengindikasikan adanya ketergantungan suatu variabel dengan dirinya sendiri secara spasial. Lee dan Wong dalam Syafitri et al. (2008) koefisien Moran's I digunakan untuk uji dependensi spasial atau autokorelasi antar amatan atau lokasi. Formula Moran's I dirumus:

$$
I=\frac{N \sum_{\mathrm{i}=1}^{\mathrm{n}} \sum_{\mathrm{j}=1}^{\mathrm{n}} \mathrm{w}_{\mathrm{ij}}\left(\mathrm{x}_{\mathrm{i}}-\overline{\mathrm{x}}\right)\left(\mathrm{x}_{\mathrm{j}}-\overline{\mathrm{x}}\right)}{\left(\sum_{\mathrm{i}=1}^{\mathrm{n}} \sum_{\mathrm{j}=1}^{\mathrm{n}} \mathrm{w}_{\mathrm{ij}}\right) \sum_{\mathrm{i}=1}^{\mathrm{n}}\left(\mathrm{x}_{\mathrm{i}}-\overline{\mathrm{x}}\right)^{2}}
$$

keterangan :

$$
\begin{aligned}
& \mathrm{I} \quad \text { : Indeks Moran (Moran Index) } \\
& \mathrm{N} \\
& \mathrm{X}_{\mathrm{i}} \\
& \text { wilayah } \mathrm{i} \\
& \text { : Jumlah kejadian variabel pada } \\
& \mathrm{X}_{\mathrm{j}} \quad \text { : Jumlah kejadian variabel pada } \\
& \text { wilayah } \mathrm{j} \\
& \overline{\mathrm{X}} \quad \text { : Re-rata dari jumlah kejadian variabel } \\
& \mathrm{x} \quad \text { : Elemen pada bobot matriks antara } \\
& \mathrm{W}_{\mathrm{ij}} \quad \text { dan } \mathrm{j} \\
& \text { wilayah } \mathrm{i}
\end{aligned}
$$

Koefisien Moran's I digunakan untuk uji dependensi spasial atau autokorelasi antar amatan atau lokasi. Hipotesis yang digunakan adalah:
$\mathrm{H}_{0}: \mathrm{I}=0$ (tidak ada autokorelasi spasial)

$\mathrm{H}_{1}: \mathrm{I}_{\neq} 0$ (ada autokorelasi spasial)

Statistik uji yang digunakan adalah sebagai berikut:

$$
Z_{\text {hitung }}=\frac{I-\mathrm{I}_{\mathrm{o}}}{\sqrt{\operatorname{var}(\mathrm{I})}} \sim N(0,1)
$$

Pengambilan keputusan tolak Ho jika $\left|Z_{\text {hitung }}\right|>Z_{\alpha / 2}$. Nilai dari indeks I adalah antara -1 dan 1. Apabila $I>I_{o}$ maka data memiliki autokorelasi positif, jika $\mathrm{I}<\mathrm{I}_{\mathrm{o}}$ maka data memiliki autokorelasi negatif.

Vasiliev dalam Arlinghaus et al. (1995) menjelaskan ketika indeks Moran mendekati 1 menunjukkan ada autokorelasi positif yang kuat, sebaliknya jika mendekati - 1 berarti terdapat autokorelasi yang negatif. Jika nilainya mendekati -1/(n-1) menunjukkan adanya distribusi nilai variabel secara random.

Selanjutnya Moran Scatterplot digunakan untuk mengidentifikasi hubungan antara nilai pengamatan yang terstandarisasi dan nilai ratarata tetangga yang sudah terstandarisasi. Peta tematik cluster kemiskinan mengikuti klasifikasi Zhukov (2010) sebagai berikut:

1. Kuadran I, HH (High-High) mengidentifikasi wilayah dengan nilai pengamatan tinggi dikelilingi oleh wilayah yang mempunyai nilai pengamatan tinggi.

2. Pada kuadran II, LH (Low-High) mengidentifikasi wilayah dengan nilai pengamatan rendah dikelilingi oleh wilayah yang mempunyai nilai pengamatan tinggi.

3. Pada kuadran III, LL (Low-low) mengidentifikasi wilayah dengan nilai pengamatan rendah dikelilingi oleh wilayah yang mempunyai nilai pengamatan rendah.

4. Pada kuadran IV, HL (High-Low) mengidentifikasi wilayah dengan nilai pengamatan tinggi dikelilingi oleh wilayah yang mempunyai nilai pengamatan rendah.

Teknik analisis spasial membutuhkan pembobot spasial yang umumnya di elaborasi dari metode ketetanggaan (contiquity) atau jarak (distance). 


\section{$\underline{\text { Pembobot Spasial }}$}

Anselin (2002) mengusulkan 3 (tiga) pendekatan untuk mendefinisikan matriks pembobot spasial (weight), yaitu contiguity, distance, dan general. Efek spasial yang menggambarkan bobot suatu wilayah amatan atas dasar ketetanggaan dengan wilayah didekatnya dalam riset ini ditentukan dengan metode Queen contiguity. Pada prakteknya matriks $\mathrm{W}$ berdasarkan persinggungan batas wilayah (contiguity) cukup sederhana dalam penerapannya. Interaksi spasial hanya mempertimbangkan adanya persinggungan batas wilayah (common boundary). Matrik W berbentuk simetrik dengan diagonal utamanya selalu bernilai nol.

Metode queen contiguity melacak adanya persinggungan sisi dan titik vertek wilayah satu dengan lainnya. Antara wilayah pengamatan ke satu dan lainnya, memiliki hubungan spasial kebertetanggaan (spatial relationship). Nilai 1 diberikan jika daerah- $i$ bertetangga dengan daerah- $j$, sedangkan nilai 0 diberikan jika wilayah- $i$ tidak berdekatan dengan wilayah- $j$. Keterkaitan spasial yang dibentuk dari kedekatan (contiguity) per kelurahan menghasilkan matriks pembobot spasial (W).

Lee dan Wong dalam Syafitri et al. (2008) menyebut matriks ini dengan binary matrix, dan biasa juga disebut connectivity matrix, yang dinotasikan dengan $C$, dan $\mathrm{c}_{\mathrm{ij}}$ merupakan nilai dalam matriks baris ke- $i$ dan kolom ke-j.

Matriks C mempunyai beberapa karakteristik. Pertama, elemen diagonal matriks $\mathrm{C}$ bernilai 0 , karena diasumsikan bahwa suatu wilayah amatan tidak berdekatan dengan dirinya sendiri. Kedua, matriks $\mathrm{C}$ merupakan matriks simetrik, matriks segitiga atas merupakan cermin dari matriks segitiga bawah. Ketiga, jumlah nilai pada baris ke- $i$ merupakan jumlah tetangga yang dimiliki oleh wilayah ke- $i$.

Notasi penjumlahan baris:

$$
C_{i}=\sum C i j
$$

keterangan:

$\mathrm{c}_{\mathrm{i}}=$ total nilai baris ke- $i$

$\mathrm{c}_{\mathrm{ij}}=$ nilai pada baris ke-i kolom ke- $j$

Binary matrik, pada dasarnya adalah matrik kontiguiti, yang digunakan untuk menentukan bobot spasial yang menggambarkan kekuatan interaksi antar titik amatan. Pada matrik kontiguiti, nilai 1 menunjukkan daerah yang bertetanggaan satu sama lain. Nilai bobot spasial $\left(\mathrm{w}_{\mathrm{ij}}\right)$ sekaligus menggambarkan besar pengaruh tetangga terhadap suatu wilayah amatan (i) dapat dihitung dari rasio antara nilai pada daerah tertentu (i) dan total nilai daerah tetangganya. Hasilnya merupakan nilai pembobotan $\left(\mathrm{w}_{\mathrm{ij}}\right)$ untuk setiap kebertetanggaan. Formulasinya adalah:

$$
\mathrm{w}_{\mathrm{ij}}=\mathrm{c}_{\mathrm{ij}} / \mathrm{c}_{\mathrm{i}}
$$

$\mathrm{W}_{\mathrm{ij}}$ : Elemen pada bobot matriks antara daerah $\mathrm{i}$ dan $\mathrm{j}$

Local Indicator of Spatial Autocorrelation $\underline{\text { LISA) }}$

Local Indicator of Spatial Autocorrelation (LISA) digunakan untuk mengidentifikasi autokorelasi spasial secara parsial atau untuk mendeteksi setiap unit amatan. Lee dan Wong (2001) menyebutkan semakin tinggi nilai lokal maka lokasi yang berdekatan memiliki nilai yang hampir sama atau membentukk suatu penyebaran yang mengelompok. Formula LISA adalah:

$$
I i=z_{i} \sum_{i=1}^{n} w_{i j} z_{j}
$$

Ii adalah nilai koefisien LISA, $z i$ dan $z j$ adalah data yang terstandarisasi dan wij merupakan pembobot antara lokasi $i$ dan $j$. Dalam perhitungan untuk penelitian ini $j$ adalah nilai amatan wilayah kelurahan yang berlokasi 
di sekitar $i$ (bukan $i$ ) sejumlah $n$. Hipotesis uji terhadap parameter LISA adalah sebagai berikut:

$\mathrm{H}_{0}: \mathrm{I}=0$ (tidak ada autokorelasi spasial lokal)

$\mathrm{H}_{1}: \mathrm{I} \neq 0$ (ada autokorelasi spsial lokal)

Uji LISA dilakukan untuk membuktikan ada tidaknya ketergantungan spasial atau efek spasial antar wilayah kelurahan secara parsial, yang pada analisis Moran's global hanya memberikan hasil analisis untuk seluruh wilayah. Dalam hal tidak semua wilayah amatan memiliki efek spasial, maka uji LISA dibutuhkan pada masing-masing lokasi yang diteliti. Pada uji dependensi ini juga menggunakan matrik pembobotan spasial. Pemberian kode pembobot adalah dengan kode biner sebagai berikut :

$$
W_{i j}=\left[\begin{array}{ll}
1 & \text { untuk i dan } \mathrm{j} \text { yang berdekatan } \\
0 & \text { untuk lainnya }
\end{array}\right.
$$

\section{HASIL DAN PEMBAHASAN}

Sebaran penduduk miskin di Kota Bengkulu menunjukkan bahwa antara pusat kota, wilayah antara dan pinggiran kota terdapat perbedaan. Konsentrasi tertinggi berlokasi di pinggiran, menurun di wilayah antara dan meningkat kembali di pusat kota.

Tabel 1. Rerata penduduk miskin berdasarkan jarak dari pusat kota

\begin{tabular}{cc}
\hline Jarak dari Pusat & Rata-rata Penduduk \\
Kota $(\mathrm{M})$ & Miskin $(\%)$ \\
\hline $0-3082$ & 17.67 \\
$3083-6165$ & 17.66 \\
$6166-9248$ & 15.85 \\
$9249-12331$ & 23.40 \\
$12332-15414$ & 38.00 \\
\hline
\end{tabular}

Gambar 2 dan gambar 3 memberikan gambaran bahwa pada wilayah pinggiran kota menuju ke arah selatan, jumlah penduduk miskin relatif tinggi yakni di kecamatan Kampung Melayu dan Selebar yang langsung berbatasan dengan Kabupaten Seluma. Hal ini sama dengan dengan tabel 1 yang memperlihatkan bahwa berdasarkan jarak dari pusat kota jumlah penduduk miskin cenderung semakin besar.

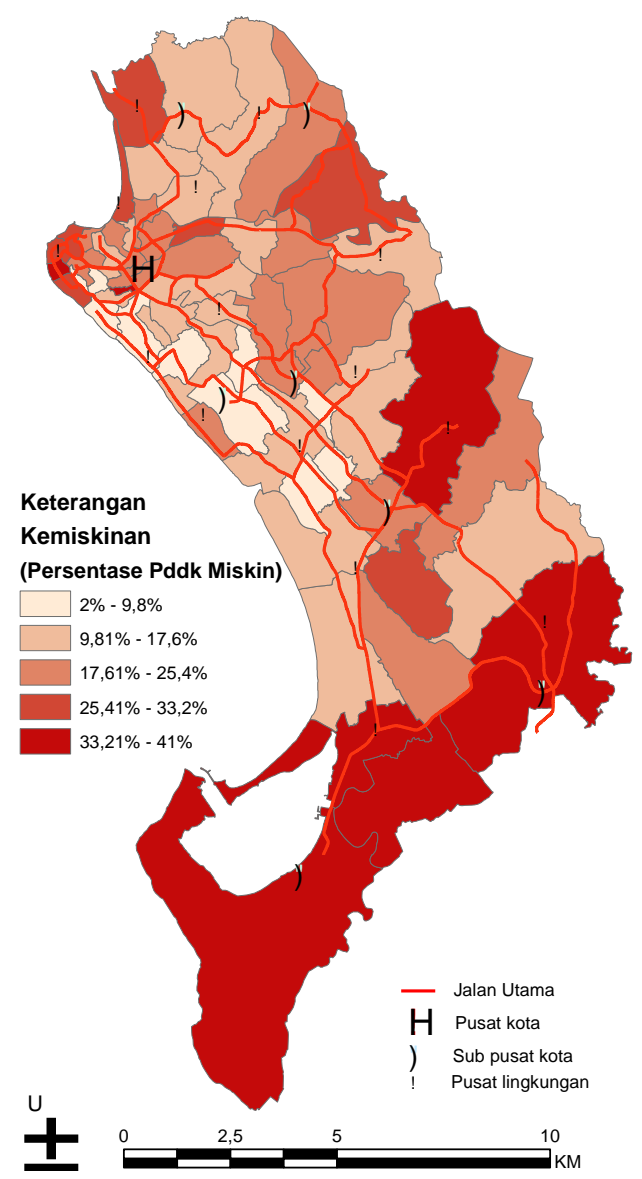

Gambar 2. Peta sebaran penduduk miskin di Kota Bengkulu

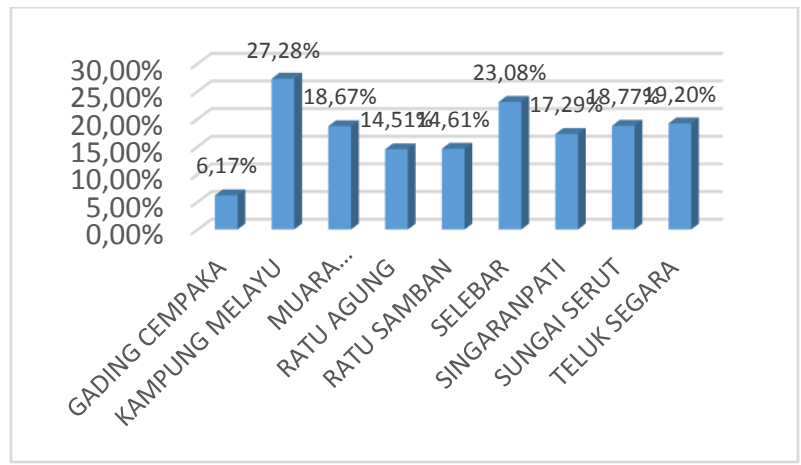

Gambar 3. Persentase jumlah penduduk miskin per Kecamatan di Kota Bengkulu 


\section{Keterkaitan Spasial (spatial contiquity)}

Hukum pertama Geografi "Tobler" mengatakan:

'Setiap hal memiliki keterkaitan dengan hal lainnya, namun yang lebih berdekatan memiliki keterkaitan lebih dari lainnya'.

Keterkaitan wilayah diukur dari adanya singgungan sisi wilayah, banyaknya wilayah yang bersinggungan akan menentukan besar kecilnya bobot spasial. Keterkaitan spasial dengan teknik queen contiquity menghasilkan beberapa kelompok wilayah berdasarkan jumlah tetangga (neighbors) yang berbeda-beda. Histogram berikut menunjukkan kelurahan dengan jumlah tetangga terendah ada 1 wilayah yakni kelurahan Teluk Sepang yang berada di sebelah selatan Kota Bengkulu. Wilayah ini langsung berbatasan dengan kabupaten tetangga yakni Seluma dan sebagian besar penggunaan lahannya adalah pertanian dengan peruntukan perkebunan sawit, ladang, rawa dan lahan kosong.

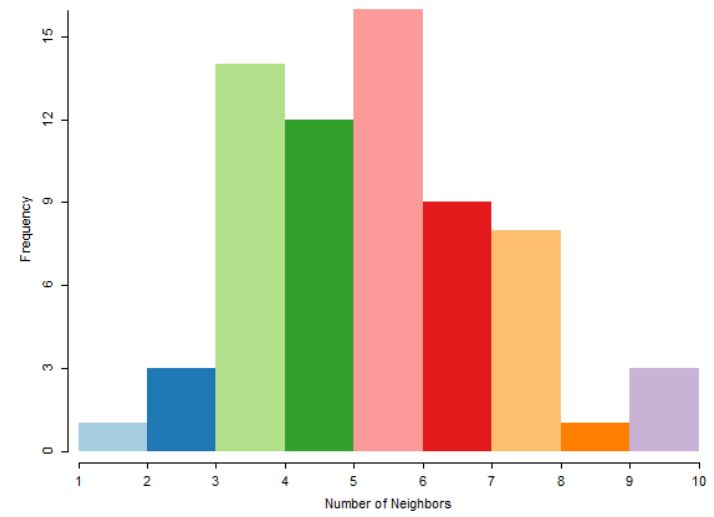

Gambar 4. Histogram ketetanggaan dengan metode queen contiquity di Kota Bengkulu

Kelurahan yang memiliki pembobot spasial terbanyak yakni 9 tetangga antara lain adalah Belakang Pondok, Pasar Melintang, Jalan Gedang, Panorama yang berlokasi di sekitar pusat kota sekaligus pusat kegiatan regional di Kota Bengkulu. Histogram di atas selain menggambarkan banyaknya jumlah tetangga (neighbors) dari masing-masing wilayah amatan, sekaligus menunjukkan bobot spasial per wilayah kelurahan.

\section{Pola Spasial Kemiskinan}

Indeks Moran sebesar 0,322 menjelaskan autokorelasi spasial yang terjadi adalah positif dan secara spasial menggerombol. Indeks ini dikenal juga sebagai global Moran yang hanya menunjukkan bahwa terdapat autokorelasi spasial untuk data kemiskinan di Kota Bengkulu, dengan pola spasialnya menggerombol.

Pola spasial positif menerangkan bahwa Penggerombolan secara spasial seperti ini terbentuk dari wilayah yang memiliki nilai amatan kemiskinan relatif sama dan letaknya saling berdekatan atau bertetangga. Dalam kenyataannya penggerombolan tidak terjadi pada satu lokasi, namun dapat menyebar diberbagai lokasi dalam wilayah amatan. Indikasi lokalitas terjadinya penggerombolan diidentifikasi dengan teknik analisis LISA.

\section{Local Indicator of Spatial Autocorrelation}

Hasil analisis data kemiskinan dengan formula LISA diperoleh adanya autokorelasi spasial lokal untuk beberapa wilayah, sedangkan sebagian lainnya tidak signifikan. Pada tingkat signifikansi 0.05 , kelurahan yang terbukti memiliki jumlah penduduk miskin dari autokorelasi spasial meliputi Kelurahan Anggut Atas, Anggut Bawah, Anggut Dalam, Bajak, Belakang Pondok, Bentiring, Bentiring Permai, Beringin Raya, Berkas, Betungan, Bumi Ayu, Cempaka Permai, Dusun Besar, Jitra, Kampung Bali, Kampung Kelawi, Kandang, Kandang Limun, Kebun Dahri, Kebun Geran, Kebun Keling, Kebun Ros, Kebun Tebeng, Lingkar Timur, Muara Dua, Padang Harapan, Padang Jati, Padang Nangka, Pagar Dewa, Panorama, Pasar Baru, Pasar Bengkulu, Pasar Melintang, Pekan Sabtu, Pematang Gubernur, Pengantungan, Pintu Batu, Pondok Besi, Rawa Makmur, Rawa Makmur Permai, Sawah Lebar, Sawah Lebar Baru, Semarang, Sidomulyo, Sukamerindu, Sukarami, Sumur Dewa, Sumur Meleleh, Tanjung Jaya, Tanjung Agung, Tengah Padang, Timur Indah. 
Kelurahan yang signifikan pada level kepercayaan 0.01 meliputi Kelurahan Anggut Atas, Anggut Bawah, Anggut Dalam, Bajak, Belakang Pondok, Bentiring, Bentiring Permai, Beringin Raya, Berkas, Betungan, Bumi Ayu, Cempaka Permai, Dusun Besar, Jembatan Kecil, Jitra, Kampung Bali, Kampung Kelawi.

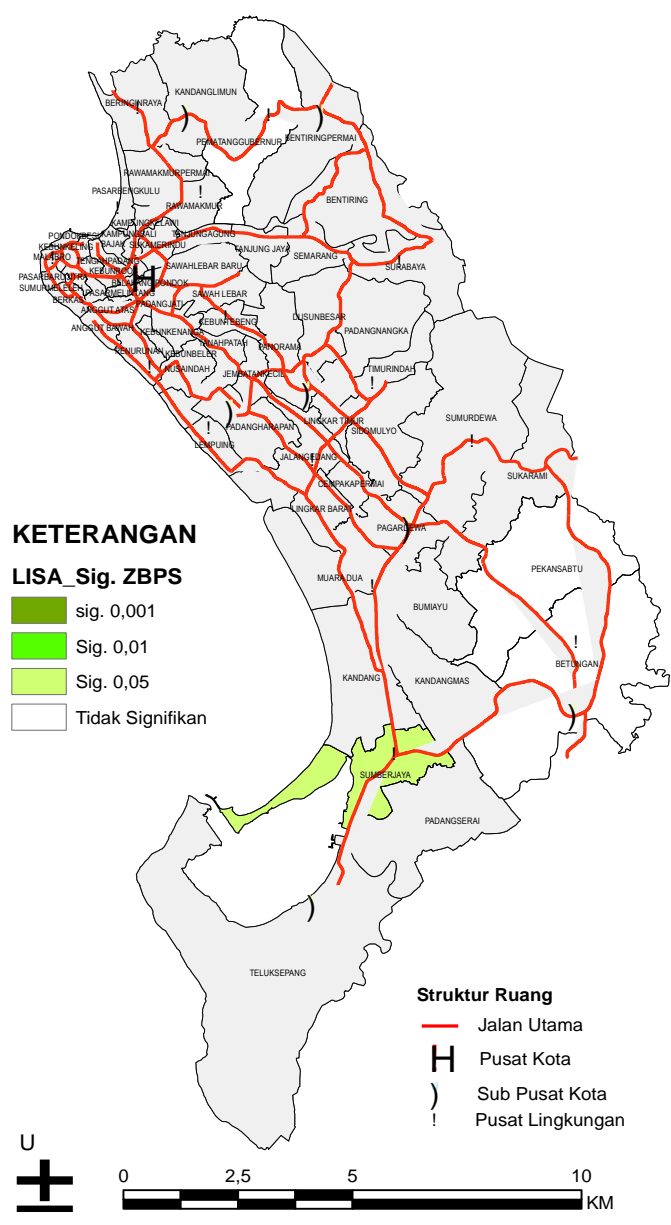

Gambar 6. Kelurahan yang memiliki autokorelasi spasial lokal pada $\alpha=0.05,0.01$ dan 0.001 .

Kandang Mas, Kebun Beler, Kebun Dahri, Kebun Geran, Kebun Keling, Kebun Ros, Kebun Tebeng, Lingkar Barat, Lingkar Timur, Malabro, Muara Dua, Nusa Indah, Padang Harapan, Padang Jati, Padang Nangka, Pagar Dewa, Panorama, Pasar Baru, Pasar Bengkulu, Pasar Melintang, Pekan Sabtu, Pematang Gubernur, Pengantungan, Penurunan, Pintu Batu, Pondok Besi, Rawa Makmur, Rawa Makmur Permai, Sawah Lebar, Sawah Lebar Baru, Semarang, Sidomulyo, Sukamerindu, Sukarami, Sumber Jaya, Sumur Dewa, Sumur
Meleleh, Surabaya, Tanjung Jaya, Tanjung Agung, Tengah Padang, Timur Indah.

Secara locational kelurahan yang kemiskinannya terbukti nyata memiliki autokorelasi spasial menyebar dari pusat kota ke arah selatan kota. Fakta adanya heterogenitas karakteristik kemiskinan seperti ini menunjukkan bahwa pendekatan program anti kemiskinan mesti bervariasi sesuai dengan kekhasan masing-masing wilayah.

\section{Moran Scatterplot}

Sama seperti pada grafik garis regresi, Moran Scatterplot mengidentifikasi derajat kecocokan dan outlier pada data kemiskinan di Kota Bengkulu.

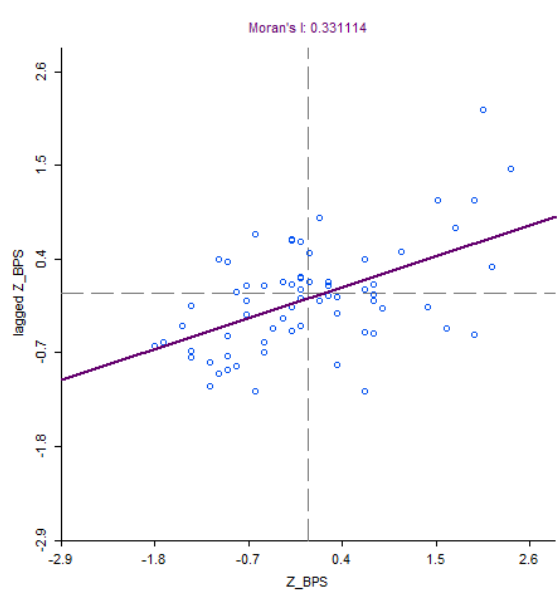

Gambar 5. Moran's I scatter plot penduduk miskin

Pemetaan tematik hasil analisis Moran'I scatter plot dipetakan dalam empat kategori wilayah yakni kuadran I, II, III, dan IV. Kuadran I wilayah dengan nilai pengamatannya tinggi di kelilingi oleh wilayah yang juga memiliki nilai pengamatan tinggi $(\mathrm{HH})$ terdiri atas kelurahan Kandang Mas, Malabro, Padang Serai, Sumber Jaya, Teluk Sepang.

Kuadran II wilayah dengan nilai pengamatan rendah, namun dikelilingi oleh wilayah dengan nilai pengamatan tingi (LH) meliputi kelurahan Jalan Gedang, Jembatan Kecil, Kebun Beler, Kebun Kenanga, Lingkar Barat, Nusa Indah, Penurunan, Tanah Patah. Kuadran III yang menunjukkan wilayah dengan nilai pengamatan rendah dan dikelilingi oleh wilayah dengan nilai pengamatan rendah (LL) 
meliputi Kelurahan Surabaya. Kuadran IV yang menunjukkan wilayah dengan nilai pengamatan tinggi dan dikelilingi oleh wilayah juga dengan nilai pengamatan rendah (HL) meliputi kelurahan Lempuing.

Cluster wilayah kemiskinan berdasarkan kuadran I, II, III dan IV pada gambar 7, menerangkan bahwa suatu wilayah miskin cenderung mengikuti kondisi wilayah tetangganya. Sehingga wilayah yang kemiskinannya rendah namun dikelilingi oleh wilayah yang kemiskinannya tinggi harus menjadi pusat perhatian agar jangan terjatuh ke dalam kondisi seperti tetangganya. Selain itu kemiskinan yang tinggi harus dilihat berdasarkan pada wilayah tetangga di sekelilingnya sehingga penetapan lokus target penanggulangan kemiskinan menjadi semakin mendekati situasi riil yang ada di masing-masing kelurahan.

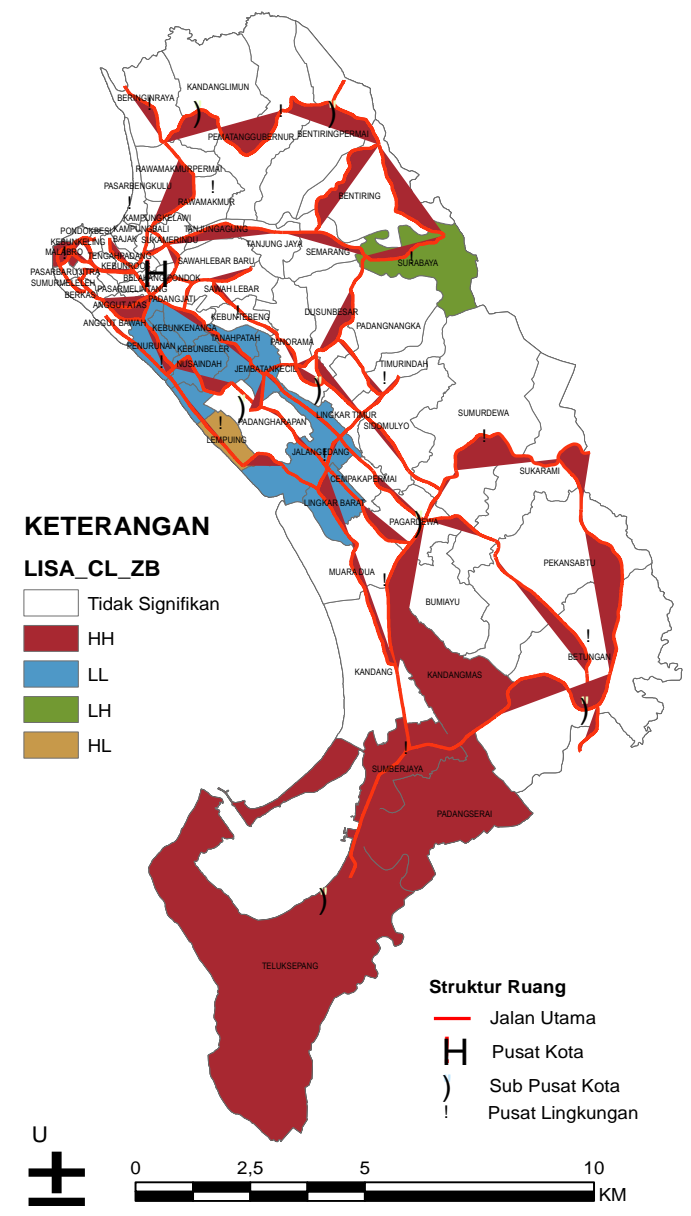

Gambar 7. Peta kluster wilayah kelurahan yang memiliki keterkaitan kemiskinan secara spasial

\section{KESIMPULAN DAN REKOMENDASI}

Nilai Indeks Moran sebesar 0,322 menjelaskan bahwa secara menyeluruh terjadi autokorelasi spasial atau terdapat ketergantungan spasial (spatial dependency) pada data kemiskinan Kota Bengkulu. Pada uji LISA untuk masing-masing wilayah kelurahan ditemukan hanya beberapa kelurahan saja yang memiliki autokorelasi spasial secara signifikan. Hal ini menunjukkan bahwa sebenarnya tidak semua wilayah kondisi kemiskinannya memiliki ketergantungan dengan wilayah lainnya, namun hanya terjadi pada lokasi-lokasi yang nilai amatannya hampir sama atau memiliki kemiripan saja.

Cluster kemiskinan yang dipetakan berdasarkan perbedaan karakteristik masingmasing wilayah, menggambarkan bahwa upaya penanggulangan kemiskinan harus memperhatikan adanya pola spasial berupa adanya ketergantungan secara spasial pada kemiskinan yang menyebabkan terbentuknya cluster gerombol kemiskinan yang diferensiatif antara satu wilayah dan wilayah lainnya. Penyeragaman kebijakan tanpa identifikasi efek spasial seperti ini dapat menyebabkan dampak kebijakan yang saling menegasikan antara satu wilayah dan lainnya, yang secara moderat akan memberikan dampak negatif pada upaya pencapaian tujuan penanggulangan kemiskinan.

Pemetaan data kemiskinan sebagai kegiatan yang mengintegrasikan dua jenis data yakni data spasial dan data atribut (konvensional) dibutuhkan untuk inovasi penelitian maupun pengembangan kebijakan anti kemiskinan. Sehubungan dengan hal tersebut pengembangan basis data spasial kemiskinan yang memiliki interoperabilitas sampai pada skala detail merupakan peluang dan tantangan yang prospektif untuk mendorong lahirnya kebijakan, rencana dan program penanggulangan kemiskinan yang sedang mengalami perlambatan. 


\section{DAFTAR PUSTAKA}

Anselin, L. (1992). Spatial Data Analysis with GIS: An Introduction to Application in The Social Sciences. California: University of California Santa Barbara.

Firmansyah, et al. (2012). Pemodelan Perkembangan Kawasan Permukiman Di Kota Surabaya Berbasis SIG. Thesis. Institut Teknologi Sepuluh Nopember.

Garvin, C. Q. (2014). Place and Poverty How Does Sprawl Affect Poverty Rates in U.S. Central Places. Disertation. California State University. Sacramento.

Hakim, L. \& Zuber, A. (2008). Dimensi Geografis dan Pengentasan Kemiskinan Pedesaan. Media Ekonomi, Jakarta: Fakultas Ekonomi Universitas Trisakti.

Instruksi Presiden Nomor 15 Tahun 2010 tentang Upaya Percepatan Penanggulangan Kemiskinan.

Juanda, B. (2009). Metodologi Penelitian Ekonomi dan Bisnis. Bogor: IPB Press.

Laderchie, et al. (2003). Does it Matter that we do not Agree on the Definition of Poverty? A Comparison of Four Approaches. Oxford Development Studies, 3 (3).

Lee, J. \& Wong, D.W.S. (2001). Statistic for Spatial Data. New York: John Wiley \& Sons.

Lipton, M. (2009). Land Reform in Developing Countries: Property rights and property wrongs. Oxfordshire: Routledge.

Purnomo, C.P., Sabekti, W.S. \& Sari, D. P. (2014). Factors and Spatial Pattern Analysis of Land Price Indonesia. FIG Congress. Kuala Lumpur.

Rustiadi, E., Saefulhakim, S., \& Panuju, D.R. (2009). Perencanaan Pengembangan Wilayah. Bogor: Crespent Press \& Yayasan Obor Indonesia.

Syafitri, U.D., Bagus, S, Salamatuttanzil. (2008). Pengujian Autokorelasi terhadap Sisaan Model Spatial Logistik, Makalah Seminar Nasional Matematika dan Pendidikan Matematika. Univeristas Negeri Yogyakarta.
Syafitri, U.D., Sholeh, A.M., \& Suprapti, P. (2008). Simulasi Radius Jarak Pengaruhnya terhadap Kebaikan Model Regresi Logistik Spasial. Makalah Seminar Nasional Matematika dan Pendidikan Matematika. Univeristas Negeri Yogyakarta.

Thaib, Z. (2008). Pemodelan Regresi Logistik Spasial dengan Pendekatan Matriks Contiquity. Skripsi. Institut Pertanian Bogor.

Vasilief, I. R. (1995). Visualization of Spatial Dependence: An Elementary View of Spatial Autocorrelation. Practical Hand Book of Spatial Statistics, 17-30. Arlinghaus

Zhukov, Y. M. (2010). Applied Spatial Statistics in R, Spatial Regression. IQSS, Harvard University. 